\title{
Floristic Change at the Drought Limit of European Beech (Fagus sylvatica L.) to Downy Oak (Quercus pubescens) Forest in the Temperate Climate of Central Europe
}

\section{Albert REIF ${ }^{1 *}$, Fotios XYSTRAKIS ${ }^{2}$, Stefanie GÄRTNER ${ }^{3}$, Uwe SAYER ${ }^{4}$}

\author{
${ }^{I}$ University of Freiburg, Faculty of Environment and Natural Resources, Chair of Site Classification and Vegetation Science, \\ Tennenbacherstr.4, D-79085 Freiburg, Germany; albert.reif@waldbau.uni-freiburg.de (*correspondingauthor) \\ ${ }^{2}$ University of Patras, Department of Environmental and Natural Resources Management, \\ G. Seferi 2, GR-30100, Agrinio, Greece; fotios.xystrakis@gmail.com \\ ${ }^{3}$ Black Forest National Park, Kniebisstr. 67, 72250 Freudenstadt, Germany; stefanie.gaertner@nlp.bwl.de \\ ${ }^{4}$ FSC Germany, Merzhauser Str. 183, 79100 Freiburgim Breisgau, Germany; uwe.sayer@fsc-deutschland.de
}

\begin{abstract}
An increase in drought could cause shifts in species composition and vegetation structure. In forests it limits the occurrence of drought sensitive tree species which become replaced by drought tolerant tree species and forest communities. Under temperate macroclimatic conditions, European beech (Fagus sylvatica L.) naturally dominates the forested landscape, except on extremely shallow soil in combination with high irradiation. On these sites beech reaches its drought limit, and is replaced by forests dominated by species like downy oak (Quercus pubescens s.l.) and English oak (Quercus petraea L). Phytosociological and ecological data were collected in the transition (ecotone) between European beach stands and stands of more drought tolerant species in order to quantify the drought intensity threshold, above which beech is replaced by drought tolerant species. It was shown that favourable topographic and soil conditions partially compensated the unsuitable climatic conditions for beech. The ecotone between these forest types was found to be characterized by shallow soils with an available soil water storage capacity of $73 \mathrm{l} / \mathrm{m}^{2}$ or less, and an irradiation intensity of $6000 \mathrm{MJ} / \mathrm{m}^{2}$ or more during the growing season. This indicates that under conditions of climate change beech would naturally still remain the dominant tree species on the majority of central European forest sites.
\end{abstract}

Keywords: downy oak, Quercus pubescens, Quercus petraea, water supply

\section{Introduction}

European beech (Fagus sylvatica L.) would naturally dominate central European temperate forests because of its high physiological shade tolerance and competitiveness (Ellenberg and Leuschner, 2010). Natural limits of beech forest appear to be relatively abrupt, a result of the ongoing high competitiveness and shade tolerance of beech even when growing close to its distribution limits (Bolte et al., 2007; Ellenberg and Leuschner, 2010). The species is able to grow under the temperate climate of central Europe in relatively dry to moist soils, yet under the subMediterranean climate of southern Europe, the competitiveness of beech is increasingly limited by climatic drought. In southern Europe growth rates and competitiveness of beech are reduced and controlled by environmental variables that indicate drought intensity (Czúcz et al., 2011; Tegel et al., 2014) and beech forests become replaced by submeridional forests composed of more drought tolerant species, mainly pines and oaks (Horvat et al., 1974; Ellenberg and Leuschner, 2010). Therefore, beech is restricted to shady slopes and/or deep soils and/or higher elevations (Ozenda et al., 1988; Peters, 1997; Reif and Löblich-Ille, 1999). In these locations, topography and soil compensate for the increasing macroclimatic drought, allowing for a "relatively constant" (Rubio and Sanchez-Palomares, 2006) water supply that favours beech. This example also demonstrates that there are various environmental factors influencing the distribution of plant species and plant communities with a scale dependent relative importance (Thuiller et al., 2003) or, in other words, according to the "rule of relative site 
constancy" (Walter, 1954), macro-climatic conditions that could potentially limit the distribution of a plant species can be partially counterbalanced by favourable, local topographic or soil factors. This explains, for example, the extrazonal distribution plant species and communities. At continental or global scale, macroclimatic variables have been proven sufficient to describe the distribution pattern of vegetation. But at local to landscape scales, disturbances, species interactions and direct physiologically effective parameters control the occurrence of plant species and plant communities. Variables influencing vegetation distribution can be broadly related to moisture, energy, nutrient availability and geomorphodynamics (Mellert et al., 2011). To study drought or aridity-induced vegetation limits, moisture supply is the main factor to be considered. It has been shown, for example, that summer drought intensity in conjunction with late spring air temperature and precipitation are the determinant factors for beech distribution at low elevations in central Europe (Czúcz et al., 2011). Moreover, soil water availability seems to actively control beech growth at its southern distribution limit (Tegel et al., 2014).

Moisture supply is defined by the complex interactions of various factors, including soil water storage capacity, precipitation, air temperature, solar radiation intensity and wind speed. All of these factors influence a site's soil water balance (Thornthwaite, 1947; Thornthwaite, 1948; Thornthwaite and Mather, 1951). The interaction of these factors can have a counterbalancing effect (i.e. high values of available soil water capacity can partially counterbalance low precipitation). In effect it could either mitigate drought intensity or, contrary, synergize to intensify drought. Different combinations of drought factors lead to particular responses in species and thus specific vegetation types.

This study focuses on the tree species composition change at the drought limit of beech in southwestern Germany and the Canton of Schaffhausen in Switzerland by studying stands at the ecotone between forests with downy oak (Quercus pubescens Willd.) including its hybrids with English oak (Quercus petraea (Matt.) Liebl.) and beech (Fig. 1) (Kätzel et al., 2014). The objective was to compare these ecotones in two regions in southwestern Germany having different macroclimatic conditions. Because site conditions are expected to induce drought at the distribution limit of beech stands, we want to relate these conditions with changes in the species composition and the performance of beech at the ecotone. Only a few studies have analysed or quantified shifts in the components of water supply on comparable sites but with different macroclimates and related them to forest vegetation responses (Rigling et al., 2013) or beech vitality (Chakraborty et al., 2013; Chakraborty et al., 2017).

\section{Materials and Methods}

\section{Study regions and locations}

The ecotones between beech and downy oak were studied at locations where forests were as near-natural as possible and the ecotone was large enough to sample along local gradients. For at least fifty years there was no harvesting in the five selected stands due to their low productivity. Even though this is not a long time when considering the lifespan of a tree, (a) it was sufficient enough that a specific ground vegetation layer, which mirrors the natural site conditions, could establish; and (b) beech was not observed regenerating in the adjacent downy oak stands indicating the near-natural limits of beech.

Ecotones between near-natural stands of downy oak and beech were sampled at five locations on Jurassic limestones with shallow rendzina soils in (1) the submontane zone of the Klettgau, including one adjacent location in Osterfingen, Switzerland, and (2) the montane zone of the central Swabian Alb (Schwaebische Alb) (Fig. 1, Table 1).

Each of the locations had downy oak stands on the driest areas, i.e., southwest exposed upper slopes, surrounded by beech-dominated forests.

\section{Vegetation assessment in the field}

To determine site gradients and where the species turnover from beech to oak forest occurred, sample plots (relevés) $10 \times 10 \mathrm{~m}$ in size were arranged in a systematic grid. The grid-lines ran in-line with the slope and had a distance of $25-30 \mathrm{~m}$ while these running along the slope had a altitudinal difference of $10-15 \mathrm{~m}$, thus the horizontal distance varied. The relevé centres were positioned at the grid-line intersections.

For each $100 \mathrm{~m}^{2}$ sample plot the vegetation was recorded. The percent cover of the vascular plants was estimated in three layers (herb, shrub and tree). A modified cover abundance scale sensu Braun-Blanquet was used (coverage $<1 \%, 1-2$ individuals: $r ; 2-5$ individuals: + ; 5-50 individuals: $\mathrm{h} ;>50$ individuals: $\mathrm{m}$; coverage $>1 \%$ to $<10 \%$ : in $1 \%$ steps; coverage $>10 \%$ : in $5 \%$ steps). The total cover of the three layers was estimated. Additional structure variables measured were (tree heights $(\mathrm{m})$; canopy cover $(\%)$; crown diameters $(\mathrm{m})$. Plant species were identified and named following Oberdorfer (2001). All introgressive hybrids between Quercus petraea and Quercus pubescens were morphologically identified following Aas (1998) and Müller

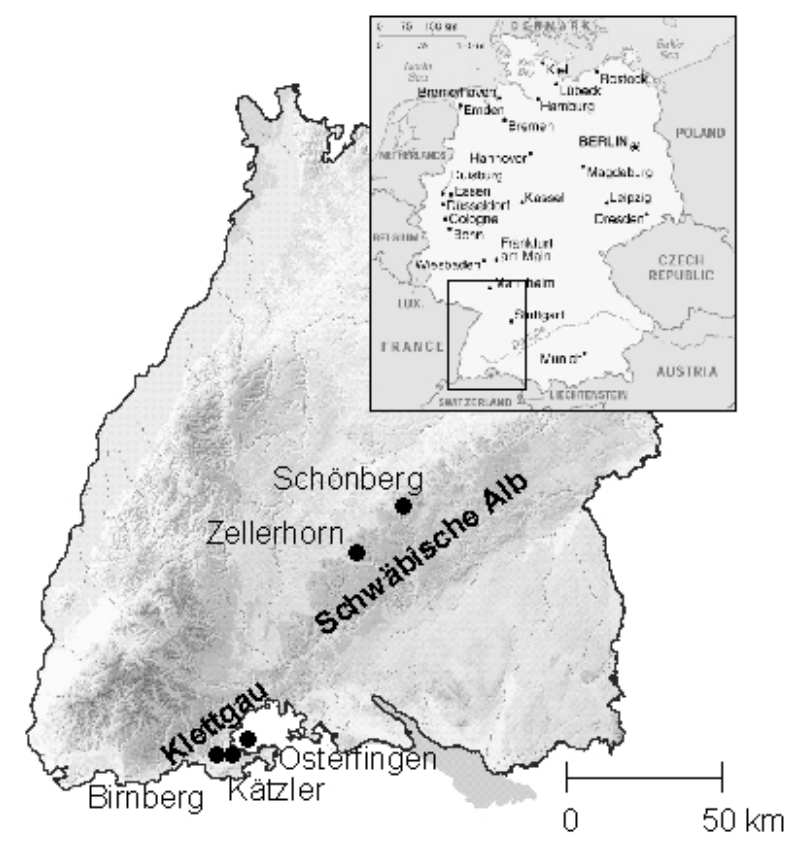

Fig. 1. The study areas 
Table 1. The two study regions, incorporating five locations

\begin{tabular}{|c|c|c|}
\hline Parameter & $\begin{array}{c}\text { Klettgau region } \\
\text { (incl. Osterfingen } / \mathrm{CH} \text { ) }\end{array}$ & Schwaebische Alb region \\
\hline $\begin{array}{l}\text { Location and number of relevés }(\mathrm{F}=\text { Fagus forest; } \\
\qquad \mathrm{ec}=\text { ecotone stand; } \mathrm{Q}=\text { Quercus forest })\end{array}$ & $\begin{array}{c}\text { Birnberg } \quad 47(16 \mathrm{~F}, 13 \mathrm{ec}, 18 \mathrm{Q}) \\
\text { Kaetzler } \quad 38(29 \mathrm{~F}, 9 \mathrm{ec}) \\
\text { Osterfingen } 56(22 \mathrm{~F}, 15 \mathrm{ec}, 19 \mathrm{Q})\end{array}$ & $\begin{array}{l}\text { Zellerhorn } 42(15 \mathrm{~F}, 12 \mathrm{ec}, 15 \mathrm{Q}) \\
\text { Schoenberg } 67(10 \mathrm{~F}, 45 \mathrm{ec}, 12 \mathrm{Q})\end{array}$ \\
\hline Elevation of site locations & $\begin{array}{ll}\text { Birnberg } & 490-550 \mathrm{~m} \\
\text { Kaetzler } & 495-555 \mathrm{~m} \\
\text { Osterfingen } & 535-620 \mathrm{~m}\end{array}$ & $\begin{array}{ll}\text { Zellerhorn } & 790-825 \mathrm{~m} \\
\text { Schoenberg } & 735-800 \mathrm{~m}\end{array}$ \\
\hline Altitudinal zone & Submontane & Montane \\
\hline Length of phenological growth period & 7.5.-13.10. (160 days) & 17.5.-2.10. (139 days) \\
\hline $\begin{array}{l}\text { Length of climatic growth period (mean daily air } \\
\text { temperature }>5^{\circ} \mathrm{C} \text { ) }\end{array}$ & 23.3.-5.11. (226 days) & 5.4.-25.10. (204 days) \\
\hline Mean annual air temperature $1961-2003$ & $9^{\circ} \mathrm{C}$ & $7^{\circ} \mathrm{C}$ \\
\hline $\begin{array}{l}\text { Mean annual air temperature data corrected after } \\
\text { interpolation }\end{array}$ & $8.6^{\circ} \mathrm{C}$ & $5.5^{\circ} \mathrm{C}$ \\
\hline Mean annual precipitation $1961-2003$ & $1012 \mathrm{~mm}$ & $834 \mathrm{~mm}$ \\
\hline $\begin{array}{l}\text { Mean annual precipitation (data corrected after } \\
\text { interpolation) }\end{array}$ & $1012 \mathrm{~mm}$ & $940 \mathrm{~mm}$ \\
\hline $\begin{array}{l}\text { Mean precipitation during climatic vegetation } \\
\text { period (Deutscher Wetterdienst, 1953) }\end{array}$ & $615 \mathrm{~mm}$ & $468 \mathrm{~mm}$ \\
\hline $\begin{array}{l}\text { Mean precipitation during phenological } \\
\text { vegetation period } \\
\text { (Deutscher Wetterdienst, 1953) }\end{array}$ & $452 \mathrm{~mm}$ & $313 \mathrm{~mm}$ \\
\hline Geology & Jurassic limestone & Jurassic limestone \\
\hline Soil & Rendzina & Rendzina \\
\hline
\end{tabular}

(1999). To determine the proportion of oak and their hybrids, a crown map of each plot was drawn. After the species samples were identified, their proportions were calculated. Finally, for each plot Ellenberg's indicator values were calculated (Ellenberg et al., 1992).

\section{Assessment and calculation of soil and climate variables \\ Edaphic variables}

The available soil water storage capacity (ASWSC) represents the edaphic water availability at each site (plot). It was derived from soil pit profiles which were distributed systematically at each location. For each profile, rooting depth, soil skeleton content, soil texture and bulk density were estimated. Humus content was analysed using the WÖSTOFF-Method. Available soil water storage capacity was calculated in $1 / \mathrm{m}^{2}$, following Arbeitskreis Standortskartierung (1996).

\section{Climatic variables \\ Air temperature and precipitation}

Precipitation and air temperature for each location were obtained from the meteorological stations of Hallau

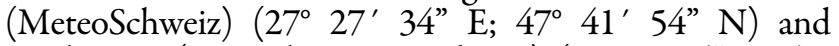
Hechingen (Deutscher Wetterdienst) ( $8^{\circ} 57^{\prime} 54^{\prime \prime} \mathrm{E}$; $48^{\circ}$ $\left.21^{\prime} 10^{\prime \prime} \mathrm{N}\right)$. The observation period (1961-2003) was considered sufficient to represent the climatic standard.

Air temperature and precipitation data for the Swabian Alb relevés were estimated by interpolating the meteorological observations from several surrounding climatic stations using altitude as auxiliary variable (Schlenker and Müller, 1973) (Table 1). For the region of Klettgau no corrections were necessary due to the proximity and elevational similarity of the Hallau climatic station to the study area.

\section{PET and irradiation intensity}

A widely used variable for describing vegetation distribution is potential evapotranspiration (PET) (Stephenson, 1998). It reflects the climatic and physiological moisture demand of a site. For the study area evaporation data was not available nor were comparisons for the best-fitting PET formulas elaborated. Instead, PET rates were estimated based on empirical formulas making use of the available weather observations. The unavailability of many climatic data variables ruled out the use of the physically based FAO Penman-Monteith formula which is considered to be the best for calculation of reference PET when it is not measured directly (Allen et al., 1998). PET therefore was obtained by means of three different irradiation-temperature formulas after Caprio (1974); Jensen and Haise (1963); and Turc (1961), all found in (Xystrakis and Matzarakis, 2010). The final PET values for each plot were calculated as the average of the three abovementioned PET values.

Irradiation intensity is an indirect variable affecting the distribution of vegetation (Sternberg and Shoshany, 2001) by affecting a site's energy balance. It highly depends on latitude, though its values can be locally modified by slope aspect and inclination. Irradiation intensity was calculated for each plot by means of DACHRAD (Fischer and Gilgen, 2002). This software calculates monthly values of irradiation intensity in $\mathrm{MJ} / \mathrm{m}^{2}$ based on latitude, but also incorporating slope aspect and inclination, elevation and sky view factor (horizon limitation). 
Although irradiation is integrated in the PET calculations, for comparison reasons irradiation has been also included separately into the set of our explanatory variables. All the calculations of PET and irradiation intensity refer to the growing season (Fischer, 1994).

\section{Humidity index}

The relationship between water supply (precipitation, $\mathrm{P})$ and evaporative demand (potential evaporation, PE) are an adequate substitute for the estimation of climatic water availability. Both factors are combined in Transeau's humidity index ( $\mathrm{HI}=\mathrm{P} / \mathrm{PE})$ (Tuhkanen, 1980). In this study potential evaporation was replaced by PET in the HI, and humidity index was calculated as $\mathrm{HI}=\mathrm{P} / \mathrm{PET}$, being suitable for comparison of climatic water availability between different sites and regions. The higher the index value the more water is available on a site. HI was calculated for the growing season for every plot.

\section{Classification of forest vegetation}

Vegetation data were classified based on the floristic composition and cover values of the species transformed to percent, and using the MULVA 5 program package (Wildi and Orlóci, 1996) with the following analysis sequence (Wildi, 1989):

- Clustering to get relevé groups (Transformations: extracting the 6. root; normalization; resemblance measure: covariance; Cluster algorithm: minimum variance).

- Ordination the species and relevés along the main gradient by applying a correspondence analysis (transformations: extracting the 6. root, double normalization of the contingency values; correspondence analysis).

- Clustering to get species groups (transformations: extracting the 6. root, normalization; resemblance measure: Chord distance; Cluster algorithm: minimum variance)

- Ordination of the relevé and species groups along the gradient by applying a concentration analysis

- Reduction of the species list to the discriminating ones by using Jancey's ranking based on F-values.

- The resulting forest types and their floristic differentiation were described in detail in Sayer (2000).

\section{Gradient Analysis}

The entire data set (257 relevés from all five locations) was analysed using a Principal Component Analysis (PCA) (ter Braak and Prentice, 1988, ter Braak, 1990). Ordination through a Detrendend Correspondence Analysis of all relevés showed a standard deviation of 2.6 units with respect to the first axis, and allowed the application of a PCA (Lepš and Šmilauer, 2003). Afterwards the principal components were correlated with the measured environmental variables. We used indirect methods since we wanted to optimally project the samples in the floristic space and later to try and explain the floristic axis of the PCA.

The PCA was carried out based on the correlation matrix of the $6^{\text {th }}$ root transformations of the species cover values. The reason was to linearise the relationship between the species as a basic assumption of applying the ordination method and to highlight the ecological meaning between the species. Ordination diagrams were projected in Euclidian distance and performed using CANOCO for Windows 4.52 (Fischer and Gilgen, 2002).

\section{Results}

\section{General vegetation patterns and environmental causes}

The results of the multivariate analysis of the floristic data were compared with the existing phytosociological classification (Oberdorfer, 1992) and summarized as "beech forest", "oak forest" and "ecotone forest" (Table 2; see also Sayer, 2000; Gaertner et al., 2008). The term "oak forest" was used to summarize relevés which were classified as Quercetum pubescenti-petraeae Imchenetzky $26 \mathrm{n}$. inv. Heinis 33, comprising sub-Mediterranean deciduous forest near its northern limit (Oberdorfer, 1992). In southern Germany, this association is rare and can be found only as isolated stands surrounded by the more frequent CariciFagetum Moor 52 (dry limestone beech forest) (Oberdorfer, 1992) to which the majority of the relevés of the "beech forest " belong. In Klettgau, few relevés of the beech forest on less dry sites were classified as Galio odoratiFagetum Rübel 30 ex Sougnez et Thill 59. The transition between oak and beech forest is gradual; however, the "ecotone forest" was clearly distinct in species composition from the beech forest. Floristically, it also was classified as Quercetum pubescenti-petraeae, because the difference between ecotone and oak forest was mainly due to tree species cover rather than ground flora. The species listed in Table 2 are reduced to those which differentiate the forest types in the two regions. A complete vegetation table containing all 257 relevés can be obtained from the authors on request.

In both regions (Klettgau and Swabian Alb) the tree species and ground vegetation change completely at the ecotone (Fig. 2, Table 2). On soils having higher SWSC, beech is dominant with some ash (Fraxinus excelsior L.) individuals mixed in. SWSC appears to be the main limiting factor for the occurrence of beech. Therefore, the more drought tolerant oak forest community is restricted to soils with a SWSC of up to $73 \mathrm{l} / \mathrm{m}^{2}$, and an irradiation of 6000 $\mathrm{MJ} / \mathrm{m}^{2}$ or more during the climatic growth period (Fig. 3). High irradiation combined with shallow soil are the site factors restricting the competiveness of beech thus allowing oak to dominate.

The oak forests are composed of oak species and their hybrids, mixed with some other tree species, whereas most adjacent beech forests belong to the Carici-Fagetum (Sayer, 2000) (Table 2, Fig. 2). The ecotone between these two forest types floristically resembles the oak forest, but beech trees with low vitality, low heights and partial crown dieback can still be found. Climatic parameters and ground vegetation composition between the two regions are different (Tables 1,2).

\section{Vegetation and site conditions in the Klettgau ecotone}

In the less humid Klettgau region the ecotone represents a more abrupt transition between beech and oak forest. On the ecotone and in the oak forest, downy oak (Quercus pubescens) and its hybrids (Quercus petraea $\times$ pubescens) prevail (Figs. 4, 5). Another frequent tree species is Sorbus 
650

Table 2. Importance (= combination of frequency and coverage) of diagnostic species of the forest formations dominated by downy oak (Quercus pubescens), beech (Fagus sylvatica), and in the transition (ecotone). Compiled data from the regions Klettgau (including the adjacent locality Osterfingen/CH) and the Schwaebische Alb

\begin{tabular}{|c|c|c|c|c|c|c|c|c|c|c|c|c|}
\hline \multirow{3}{*}{$\frac{\text { Climate (elevational zone) }}{\text { Forest formation }}$} & \multicolumn{6}{|c|}{ Klettgau (incl. Osterfingen/CH) Osterfingen/CH) } & \multicolumn{6}{|c|}{ Schwaebische Alb } \\
\hline & \multicolumn{6}{|c|}{ Submontane } & \multicolumn{6}{|c|}{ Montane } \\
\hline & \multicolumn{2}{|c|}{ Quercus } & \multicolumn{2}{|c|}{ Ecotone } & \multicolumn{2}{|c|}{ Fagus } & \multicolumn{2}{|c|}{ Quercus } & \multicolumn{2}{|c|}{ Ecotone } & \multicolumn{2}{|c|}{ Fagus } \\
\hline [All numbers are \%] & 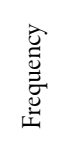 & 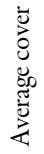 & 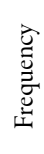 & 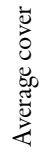 & 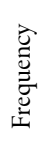 & 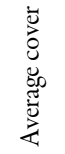 & 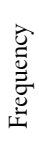 & 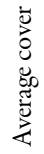 & 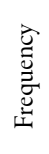 & 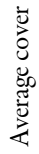 & 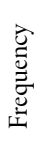 & 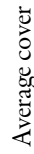 \\
\hline
\end{tabular}

$\begin{array}{cr}\text { Quercus petraea } \times \text { pubescens } & 100 \\ \text { Fragaria viridis } & 41 \\ \text { Species mainly in submontane oak forest (Klettgau) }\end{array}$

\begin{tabular}{|c|c|c|c|c|c|c|c|c|c|c|c|c|}
\hline Quercus pubescens & 62 & 7.4 & 51 & 6.8 & 6 & 0.4 & 48 & 5.7 & 9 & 1.1 & 4 & 0.6 \\
\hline Calamintha menthifolia & 78 & 0.3 & 57 & 0.2 & & & 37 & 0.2 & 2 & $<0.1$ & 4 & $<0.1$ \\
\hline Sorbus torminalis & 14 & 0.8 & 32 & 1.2 & 11 & 0.2 & & & & & & \\
\hline Coronilla emerus & 73 & 0.3 & 65 & 0.2 & 41 & 0.1 & & & & & & \\
\hline Dictamnus albus & 51 & 0.2 & 43 & 0.2 & 15 & $<0.1$ & & & & & & \\
\hline Asperula tinctoria & 27 & 0.1 & 14 & $<0.1$ & 1 & $<0.1$ & 4 & $<0.1$ & & & & \\
\hline ithospermum purpurocaeruleum & 16 & $<0.1$ & 30 & 2.5 & 1 & 0.1 & 4 & $<0.1$ & & & 8 & 0.1 \\
\hline Teucrium chamaedrys & 73 & 0.5 & 32 & 0.2 & & & & & 2 & $<0.1$ & & \\
\hline Melittis melissophyllum & 95 & 0.4 & 81 & 0.3 & 56 & 0.2 & & & & & & \\
\hline Euonymus europaeus & 62 & 0.2 & 70 & 0.2 & 45 & 0.1 & 7 & $<0.1$ & 2 & $<0.1$ & 8 & $<0.1$ \\
\hline Hedera belix & 97 & 0.5 & 92 & 0.5 & 96 & 0.4 & 7 & $<0.1$ & 63 & 0.9 & 72 & 0.5 \\
\hline
\end{tabular}

Species mainly in montane oak forest (Schwaeb. Alb)

\begin{tabular}{|c|c|c|c|c|c|c|c|c|}
\hline Laserpitium latifolium & 1 & $<0.1$ & 89 & 0.8 & 37 & 0.1 & 20 & $<0.1$ \\
\hline Thesium bavarum & & & 67 & 0.1 & 28 & $<0.1$ & 4 & $<0.1$ \\
\hline Calamagrostis varia & & & 63 & 16.0 & 40 & 2.6 & 36 & 1.5 \\
\hline
\end{tabular}

Mesophytic species of deciduous forest

\begin{tabular}{|c|c|c|c|c|c|c|c|c|c|c|c|c|}
\hline \multirow{2}{*}{ Fagus sylvatica } & \multirow[b]{2}{*}{5} & \multirow{2}{*}{1.4} & \multirow{2}{*}{46} & \multirow[b]{2}{*}{10.2} & & & & \multirow{2}{*}{45.7} \\
\hline & & & & & 100 & 64.9 & 11 & 1.7 & 67 & 18.4 & 92 & \\
\hline Phyteuma spicatum & & & & & 7 & $<0.1$ & 41 & 0.1 & 53 & 0.2 & 76 & 0.2 \\
\hline Convallaria majalis & 24 & 0.1 & 19 & 0.2 & 52 & 0.3 & 11 & 0.1 & 54 & 0.4 & 68 & 0.5 \\
\hline Abies alba & & & & & & & & & & & 16 & 0.9 \\
\hline
\end{tabular}

Light demanding tree species

$$
\begin{aligned}
& \text { Quercus petraea } \\
& \text { Fraxinus excelsior } \\
& \text { Acer campestre }
\end{aligned}
$$

Light demanding species of the ground flora

$$
\begin{gathered}
\text { Brachypodium pinnatum } \\
\text { Geranium sanguineum } \\
\text { Sesleria varia }
\end{gathered}
$$

\begin{tabular}{ccccccccccccc}
59 & 7.5 & 68 & 7.7 & 49 & 4.3 & 96 & 23.6 & 89 & 31.8 & 48 & 6.2 \\
32 & 1.6 & 57 & 10.0 & 44 & 6.8 & 67 & 9.3 & 77 & 14.7 & 68 & 13.7 \\
16 & 0.6 & 43 & 2.0 & 18 & 0.6 & 33 & 1.0 & 47 & 6.6 & 36 & 2.9 \\
\hline 11 & 0.1 & 5 & $<0.1$ & 1 & $<0.1$ & 63 & 11.0 & 26 & 1.3 & 4 & 1.8 \\
11 & $<0.1$ & 5 & $<0.1$ & & & 78 & 0.2 & 11 & $<0.1$ & & \\
32 & 0.1 & 8 & $<0.1$ & & & 30 & 1.5 & 42 & 1.5 & 40 & 3.0 \\
\hline
\end{tabular}

torminalis (L.) Crantz. In the understory the thermophilous shrub Hippocrepis emerus (L.) Lassen subsp. emerus (=Coronilla emerus L.) and the herbs Dictamnus albus, Asperula tinctoria L., Aegonychon purpurocaeruleum (L.) Holub (=Lithospermum purpurocaeruleum L.), Teucrium chamaedrys L. (Table 2) along with other species were found.

Vegetation and site conditioms in the Swabian Alb ecotone

In the montane Swabian Alb the ecotone boundaries are slightly less abrupt. Downy oak is able to grow only on the driest sites and was absent on the ecotone relevés (Figs. 2, 4). The hybrids Quercus petraea $\times$ pubescens were also reduced in terms of frequency and cover (Figs. 2, 5). Instead of oaks, beech, Quercus petraea (Fig. 6), Acer campestre L, Fraxinus excelsior L. and Sorbus aria (L.) Crantz were more prominent, resulting an ecotone relatively rich in tree species (Fig. 2). Overall the tree species cover was lower and the ground vegetation cover higher. Differential species include Laserpitium latifolium L., Thesium linophyllon subsp. montanum (Schrad.) Čelak. (=Thesium bavarum

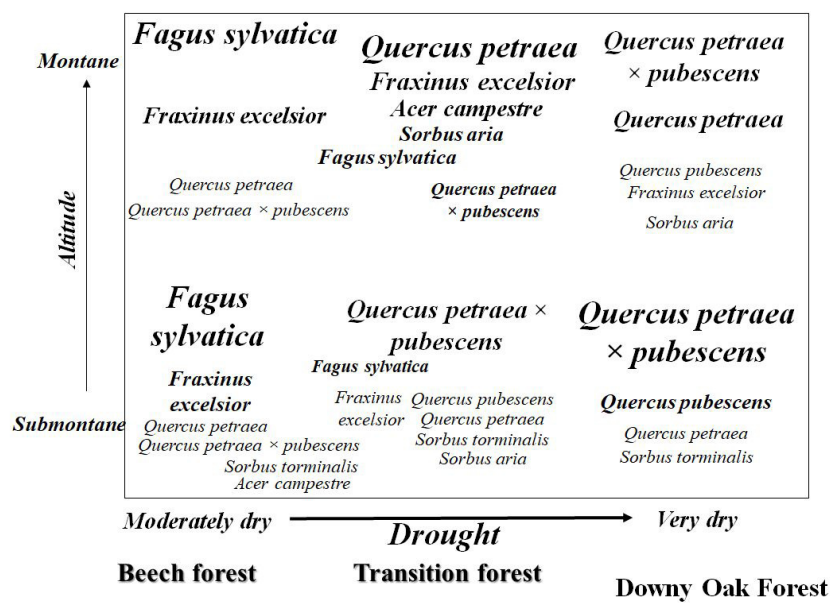

Fig. 2. Ecogram of the principal tree species occurring in limestone forests in the ecotones between beech and downy oak forests. The drought and altitude gradients lead to a distinct shift in the competitiveness of the tree species. The font size represents the relative significance of the species (mean coverage rates) 
Schrank) and Calamagrostis varia (Schrad.) Host (Table 2). Interactions of drought components

In the submontane Klettgau region temperatures and precipitation are higher and the growing season longer compared to the montane Swabian Alb region (Table 2).

In both regions, beech was able to grow on sites reflecting similar SWSC values (Fig. 3). However, the ecotone in the Swabian Alb occurred on sites with slightly lower SWSC values as those of the oak forest in Klettgau (Fig. 7). Beech forest in Klettgau was confined to soils having a SWSC of $>65 \mathrm{l} \mathrm{m}-^{2}$, whereas in the more humid Swabian Alb region beech was able to survive in soils having a SWSC of $60 \mathrm{~lm}^{-2}$ (Fig. 7).

The Transeau's humidity index (Tuhkanen, 1980) during the growing season expressed as humidity index $\mathrm{HI}$ was higher in the Swabian Alb than in the Klettgau (Fig. 7). This is reflected in the SWSC of the ecotone representing

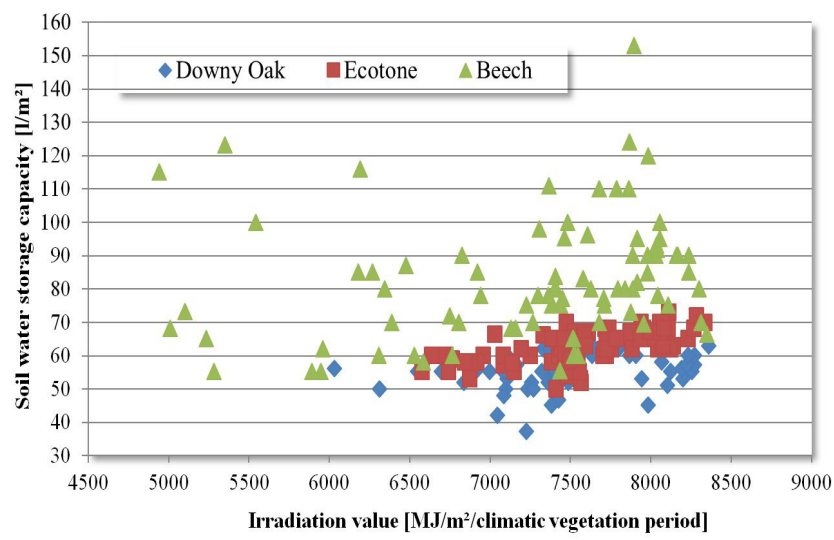

Fig. 3. The relationship between soil water storage capacity (SWSC), irradiation value during the climatic growth period, and forest formation. Oak forest is restricted to soils with a SWSC of up to $731 / \mathrm{m}^{2}$, and an irradiation of $6000 \mathrm{MJ} / \mathrm{m}^{2}$ or more

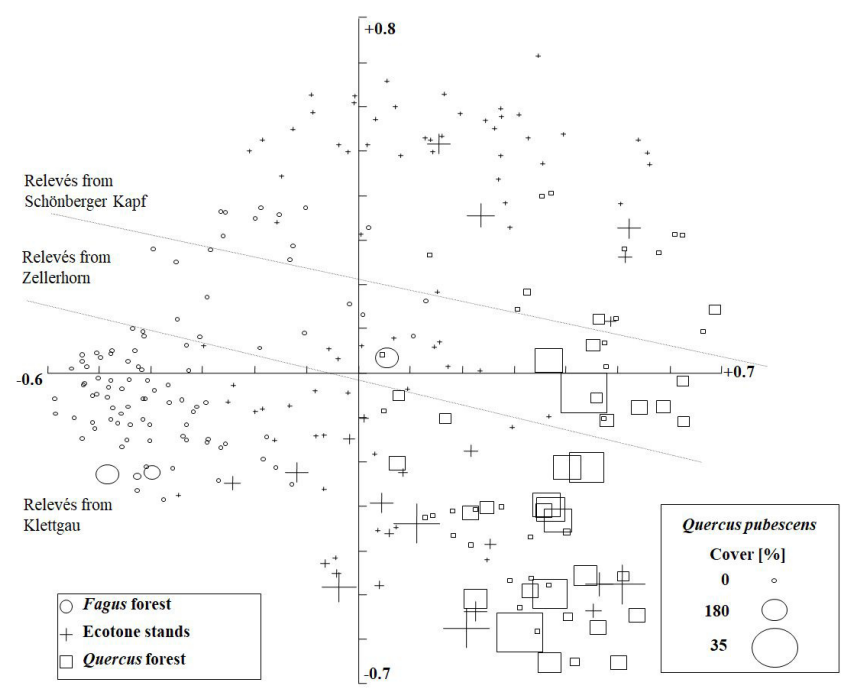

Fig. 4. Quercus pubescens was found with higher cover values in the Quercus forests and ecotone stands of the submontane Klettgau, compared to the montane Schwäbische Alb (Schönberger Kapf, Zellerhorn). PCA of the whole data set. The symbol form represents the forest type, its size indicates the coverage of the species the drought limit of beech. In the less humid Klettgau, all thresholds between the forest types occur on sites with significantly higher SWSC compared with the Swabian Alb (Fig. 7).

The consistency of this pattern demonstrates a droughtdependent shift of the ecotone and the occurrence of intermediate forest types between those regions. The climatic and edaphic factors between these regions are different.

\section{Discussion}

It can be expected that climate change will also affect the growth and vitality of beech or eventually influence its distribution limit as shown by many studies (Gessler $e$ t al.,

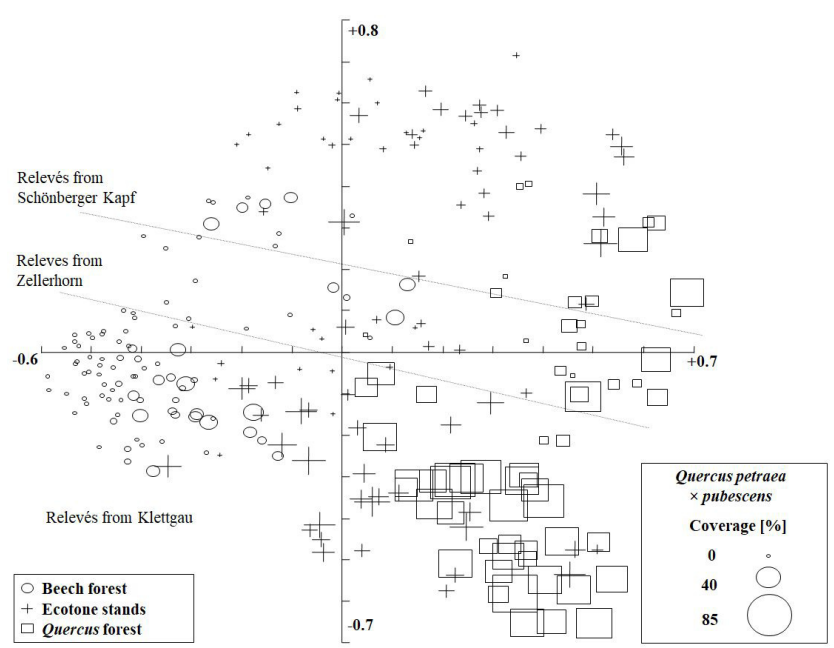

Fig. 5. The hybrid Quercus petraea $\times$ pubescens was the most important taxon in the Quercus forest and the ecotone stands of the submontane Klettgau region. In the montane Schwäbische Alb (Zellerhorn, Schönberger Kapf), the hybrid was less dominant. PCA of the whole data set. The symbol form represents the forest type, its size indicates the coverage of the species

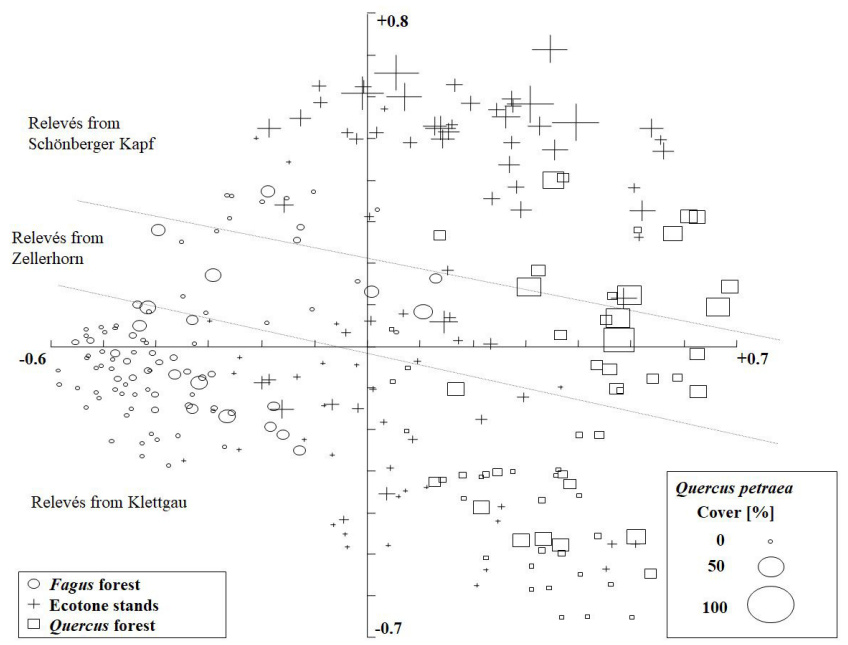

Fig. 6. In the montane Schwäbische Alb (Schönberger Kapf, Zellerhorn), Quercus petraea dominates the ecotone stands and was found with high cover values in the Quercus forest, whereas it was infrequent in the submontane Klettgau plots. PCA of the whole data set. The symbol form represents the forest type, its size indicates the coverage of the species 
652

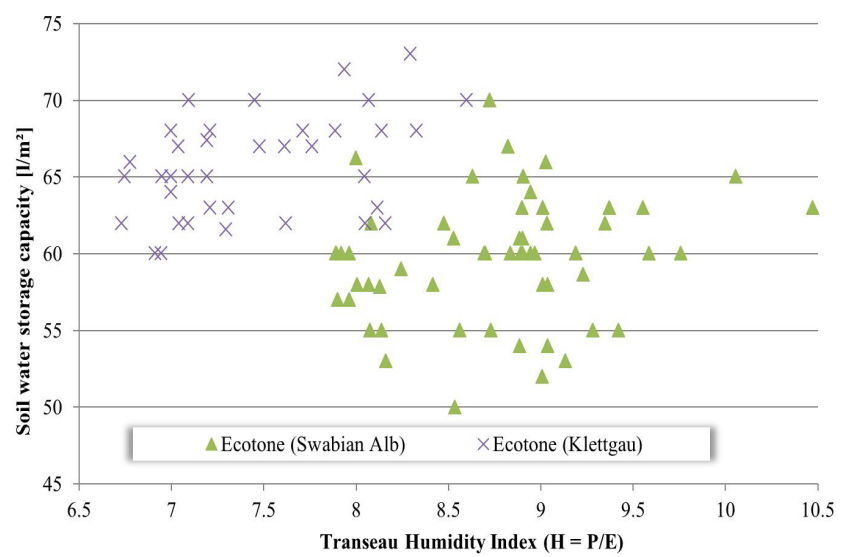

Fig. 7. The relationship between water supply in the soil, vegetation and the Transeau Humidity Index $(\mathrm{H}=\mathrm{P} / \mathrm{E} ; \mathrm{P}=$ precipitation, $\mathrm{E}=$ potential evaporation). The Humidity Index clearly shows the mesoclimatical differences between the two regions (submontane Klettgau and montane Schwaebische Alb)

2007, Scharnweber et al., 2011, Cavin et al., 2013, Tegel et al., 2014, Zimmermann et al., 2015). An increase in temperature alone can be tolerated by beech as it is able to grow in regions with a mean annual temperature of $14{ }^{\circ} \mathrm{C}$ (Peters, 1997, Kölling et al., 2007) and may even grow faster when sufficiently supplied with water (Felbermeier, 1993, Pretzsch and Durský, 2002)). Cavin and Jump (2017) found that populations of European beech at the driest part of its distribution exhibit particularly high resistance to drought and showed little evidence of recent drought-linked growth decline. Instead the greatest sensitivity and lowest resistance was observed in populations near the core of the species range.

In this study it was shown that at a local scale and under temperate macroclimatic conditions beech was the dominant tree species in all forests except those found on extremely shallow soils combined with high irradiation on south-western facing slopes. At this ecotone beech trees showed higher mortality, lower resilience and higher climate dependency compared to the adjacent less dry sites (Chakraborty et al., 2013, Chakraborty et al., 2017). This supports the argumentation that drought affects the vitality and growth rates well before it induces distribution shifts (Weber et al., 2013).

In both regions of this study, drought intensity that limits the occurrence of beech is defined by the interaction of edaphic and climatic drivers which supports the argumentation of a simultaneous climatic-edaphic expression of drought (Weber et al., 2013). Our results demonstrated that the consideration of the relative site constancy rule, i.e. the interaction of edaphic and topographic features can be used to improve the quantification of drought and compare sites that do not share the same macroclimatic conditions. It is generally agreed that with a more local the scale, edaphic, landscape and biotic factors should gain in importance in explaining species distribution (Pearson and Dawson, 2003). The relatively high precipitation in the Klettgau region results in an higher humidity ("lower demand"), which allows beech to advance to slightly shallower soils ("lower supply"), providing "relatively" the same water supply. From this point of view the drought stress intensity on the ecotone can be regarded as similar in both regions. This combination of soil, topographic and climatic data allows for the quantification and description of the ecological features of the ecotone between oaks and beech in great detail. However, we cannot exclude the possibility that additional parameters other than those considered here may also play a role.

Between the two regions examined there are also differences that are related to the length of the growing season. The lower temperatures, precipitation and humidity along with a shorter growing season in the Swabian Alb result in less plant growth (biomass production), compared to the Klettgau region. This affects the vitality, frequency and percent ground cover of all species including the ground vegetation and the tree species composition.

\section{Conclusions}

Our results demonstrate the need to include edaphic and topographic variables in modelling procedures in order to increase the accuracy of the quantification of the distributional limits of tree species (Fang and Lechowicz, 2006). Our results, combined with further research in additional sites, are a stepping stone for the analysis of the interactions between factors acting at different spatial scales. It is proposed that in species distribution modelling, the importance of local, topographic variations should always be tested even when the distribution modelling refers to large geographic areas before assuming that only climate is sufficient to explain distribution patterns at large scales (Austin and Van Niel, 2011).

Based on our findings it can be expected that beech will be replaced on sites near its drought limit in central Europe. The first effects will presumably be increased regeneration and understory beech mortality (Chakraborty et al., 2013, Chakraborty et al., 2017).

\section{Acknowledgements}

This work was supported by the Deutsche Forschungsgemeinschaft grant number RE 579/1-3.

\section{References}

Aas G (1998). Morphologische und ökologische Variation mitteleuropäischer Quercus-Arten: Ein Beitrag zum Verständnis der Biodiversität, IHW-Verlag

Allen R, Pereira L, Raes D, Smith M (1998). Crop evapotranspirationGuidelines for computing crop water requirements-FAO Irrigation and drainage paper 56.FAO, Rome.

Arbeitsgemeinschaft Standortskartierung (1996). Forstliche Standortsaufnahme, Eching: IHW-Verlag

Austin MP, Van Niel KP (2011). Improving species distribution models for climate change studies: variable selection and scale. Journal of Biogeography38(1):1-8. 
Bolte A, Czajkowski T, Kompa T (2007). The north-eastern distribution range of European beech - a review. Forestry 80(4):413-429.

Caprio J (1974). The solar thermal unit concept in problems related to plant development and potential evapotranspiration. In: Lieth H (Ed). Phenology and Seasonality Modeling. Springer Verlag, New York pp 353-364.

Cavin L, Jump AS (2017). Highest drought sensitivity and lowest resistance to growth suppression are found in the range core of the tree Fagus sylvatica L. not the equatorial range edge. Global Change Biology 23(1):362-379.

Cavin L, Mountford EP, Peterken GF, Jump AS (2013). Extreme drought alters competitive dominance within and between tree species in a mixed forest stand. Functional Ecology 27(6):14241435.

Chakraborty T, Saha S, Matzarakis A, Reif A (2017). Influence of multiple biotic and abiotic factors on the crown die-back of European beech trees at their drought limit. Flora 229:58-70.

Chakraborty T, Saha S, Reif A (2013). Decrease in available soil water storage capacity reduces vitality of young understorey European beech (Fagus sylvatica L.) - A case study from the Black Forest, Germany. Plants 2(4):676.

Czúcz B, Gálhidy L, Mátyás C (2011). Present and forecasted xeric climatic limits of beech and sessile oak distribution at low altitudes in Central Europe. Annals of Forest Science 68(1):99-108.

Ellenberg H, Weber HE, Düll R, Wirth V, Werner W, Paulißen D (1992). Zeigerwerte von Pflanzen in Mitteleuropa. Verlag Erich Goltze KG, Göttingen.

Ellenberg H, Leuschner C (2010). Vegetation Mitteleuropas mit den Alpen, in ökologischer, dynamischer und historischer Sicht, Stuttgart, Ulmer Verlag.

Fang J, Lechowicz MJ (2006). Climatic limits for the present distribution of beech (Fagus L.) species in the world. Journal of Biogeography 33(10):1804-1819.

Felbermeier B (1993). Einfluss von Klimaänderungen auf die Areale von Baumarten, München, Lehrstuhl für Waldbau und Forsteinrichtung der Ludwig-Maximilians-Univ.

Fischer H, Gilgen H (2002). DACHRad-Berechnung der direkten Sonneneinstrahlung in Deutschland, Österreich und der Schweiz. Bulletin of the Geobotanical Institute ETH 68:83-94.

Fischer HS (1994). Simulation der räumlichen Verteilung von Pflanzengesellschaften auf der Basis von Standortskarten. Dargestellt am Beispiel des MaB-Testgebiets Davos. Veröff Geobot Inst ETH, Stiftung Rübel.Zürich.

Gärtner S, Reif A, Xystrakis F, Sayer U, Bendagha N, Matzarakis A (2008). The drought tolerance limit of Fagus sylvatica forest on limestone in southwestern Germany. Journal of Vegetation Science 19:757-768.

Gessler A, Keitel C, Kreuzwieser J, Matyssek R, Seiler W, Rennenberg H (2007). Potential risks for European beech (Fagus sylvatica L.) in a changing climate. Trees-Structure and Function 21(1):1-11.

Horvat I, Glavac V, Ellenberg H (1974). Vegetation Südosteuropas. Stuttgart, G Fischer.
Jensen M, Haise H (1963). Estimating evapotranspiration from solar radiation. US Dept. of Agriculture, Agricultural Research Service, Soil and Water Conservation Research Division.

Kätzel R, Kamp T, Höltken AM, Becker F, Riederer HJ, Schröder J (2014). Die Vorkommen der Flaum-Eiche und ihrer Hybriden nördlich der Alpen. Landbauforschung Applied Agricultural and Forestry Research 64(2):73-84.

Kölling C, Zimmermann L, Walentowski H (2007). Entscheidungshilfen für den klimagerechten Waldumbau in Bayern. Klimawandel: Was geschieht mit Buche und Fichte? AFZ/Der Wald 11:584-588.

Lepš J, Šmilauer P (2003). Multivariate analysis of ecological data using CANOCO, Cambridge, UK, Cambridge University Press.

Mellert KH, Fensterer V, Küchenhoff H, Reger B, Kölling C, Klemmt HJ, Ewald J (2011). Hypothesis-driven species distribution models for tree species in the Bavarian Alps. Journal of Vegetation Science 22(4):635-646.

Müller B (1999). Variation und Hybridisierung von Quercus pubescens. Diss., Eidgenoessische Technische Hochschule Zürich.

Oberdorfer E (1992). Süddeutsche Pflanzengesellschaften Teil IV: Wälder und Gebüsche (Tabellenband). Stuttgart, Gustav Fischer.

Oberdorfer E (2001). Pflanzensoziologische Exkursionsflora für Deutschland, Stuttgart, Ulmer.

Ozenda P, Mayer H, Zirnig A (1988). Die Vegetation der Alpen im europäischen Gebirgsraum, Gustav Fischer.

Pearson RG, Dawson TP (2003). Predicting the impacts of climate change on the distribution of species: are bioclimate envelope models useful? Global Ecology and Biogeography 12(5):361-371.

Peters R (1997). Beech forests, Kluwer Academic Publishers.

Pretzsch H, Durský J (2002). Growth reaction of Norway Spruce (Picea abies (L.) Karst.) and European Beech (Fagus silvatica L.) to possible climatic changes in Germany. A sensitivity study. Forstwissenschaftliches Centralblatt 121:145-154.

Reif A, Löblich-Ille K (1999). Sind die Rotbuchenwälder im PieriaGebirge (Nordgriechenland) höhenzonal oder extrazonal? Eine Studie zum Übergang zwischen temperaten und submediterranen Wäldern in Nordgriechenland. Phytocoenologia 29(1):87-146.

Rigling A, Bigler C, Eilmann B, Feldmeyer-Christe E, Gimmi U, Ginzler C, ... Dobbertin M (2013). Driving factors of a vegetation shift from Scots pine to pubescent oak in dry Alpine forests. Global Change Biology 19(1):229-240.

Rubio A, Sanchez-Palomares O (2006). Physiographic and climatic potential areas for Fagus sylvatica L. based on habitat suitability indicator models. Forestry 79(4):439.

Sayer U (2000). Die Ökologie der Flaumeiche (Quercus pubescens Willd.) und ihrer Hybriden auf Kalkstandorten an ihrer nördlichen Arealgrenze (Untersuchungen zu Boden, Klima und Vegetation). Stuttgart, J Cramer.

Scharnweber T, Manthey M, Criegee C, Bauwe A, Schröder C, Wilmking M (2011). Drought matters - Declining precipitation influences growth of Fagus sylvatica L. and Quercus robur L. in north-eastern Germany. Forest Ecology and Management 
654

262(6):947-961.

Schlenker G, Müller S (1973). Erläuterungen zur Karte der Regionalen Gliederung von Baden-Württemberg I. Teil (Wuchsgebiete Neckarland und Schwäbische Alb). Mitt. Ver. Forstl. Standortsk. Forstpflanzenz 23:3-66.

Stephenson N (1998). Actual evapotranspiration and deficit: biologically meaningful correlates of vegetation distribution across spatial scales. Journal of Biogeography 25(5):855-870.

Sternberg M, Shoshany M (2001). Influence of slope aspect on Mediterranean woody formations: Comparison of a semiarid and an arid site in Israel. Ecological Research 16(2):335-345.

Tegel W, Seim A, Hakelberg D, Hoffmann S, Panev M, Westphal T, Büntgen U (2014). A recent growth increase of European beech (Fagus sylvatica L.) at its Mediterranean distribution limit contradicts drought stress. European Journal of Forest Research 133(1):61-71.

ter Braak C (1990). Update notes: CANOCO version 3.10. Agricultural Mathematics Group, Wageningen 35.

ter Braak C, Prentice I (1988). A theory of gradient analysis. Advances in Ecological Research 18:271-317.

Thornthwaite CW (1947). Climate and moisture conservation. Annals of the Association of American Geographers 37(2):87100.

Thornthwaite CW (1948). An approach towards a rational classification of climate. Geographical Review 38(1):55-94.

Thornthwaite CW, Mather JR (1951). The role of evapotranspiration in climate. Theoretical and Applied Climatology 3(1):16-39.
Thuiller W, Araújo MB, Lavorel S (2003). Generalized models vs. classification tree analysis: Predicting spatial distributions of plant species at different scales. Journal of Vegetation Science 14(5):669-680.

Tuhkanen S (1980). Climatic parameters and indices in plant geography. Almqvist \& Wiksell International.

Turc L (1961). Evaluation des besoins en eau d'irrigation, evapotranspiration. Ann Agron 12:13-49.

Walter H (1954). Einführung in die Phytologie, III. Grundlagen der Pflanzenverbreitung, 2. Teil: Arealkunde. Stuttgart: Ulmer.

Weber P, Bugmann H, Pluess AR, Walthert L, Rigling A (2013). Drought response and changing mean sensitivity of European beech close to the dry distribution limit. Trees 27(1):171-181.

Wildi O (1989). A new numerical solution to traditional phytosociological tabular classification. Plant Ecology 81(1):95106.

Wildi O, Orlóci L (1996). Numerical exploration of community patterns: a guide to the use of MULVA-5. SPB Academic Publishing.

Xystrakis F, Matzarakis A (2010). Evaluation of 13 empirical reference potential evapotranspiration equations on the island of Crete in Southern Greece. Journal of Irrigation and Drainage Engineering 137(4):211-222.

Zimmermann J, Hauck M, Dulamsuren C, Leuschner C (2015). Climate warming-related growth decline affects Fagus sylvatica, but not other broad-leaved tree species in Central European mixed forests. Ecosystems 18(4):560-572. 